\title{
Response of Tuberose (Polianthes tuberosa L.) cv. Pajwal to Flower Inducing Chemicals
}

\author{
R. Naga Lakshmi ${ }^{1 *}$, M. Lakshminarayana Reddy ${ }^{2}$, B. V. K. Bhagavan ${ }^{1}$, A. V. D. Dorajee \\ Rao $^{3}$, P. Subbaramamma ${ }^{3}$ and K. Uma Krishna ${ }^{3}$ \\ ${ }^{1}$ Horticultural Research Station, Kovvur, ${ }^{2}$ Dean of Horticulture, ${ }^{3}$ College of Horticulture, \\ Venkataramannagudem, Dr YSR Horticultural University, Andhra Pradesh, India \\ *Corresponding author
}

\section{A B S T R A C T}

Keywords

Tuberose, Prajwal, Flower inducing chemicals,

Flowering, Spike yield

Article Info

Accepted:

15 December 2019

Available Online:

20 January 2020
The present experiment was aimed to evaluate different flower inducing chemicals on flowering of tuberose (Polianthes tuberosa L.) cv. Prajwal at Horticultural Research Satiation, Kovvur, Andhra Pradesh during the years 2015-16 and 2016-17. Experiment conducted with 11 treatments which includes spraying of $\mathrm{GA}_{3}, \mathrm{BA}, \mathrm{SA}$, spermidine, ethephon each at two concentrations at 30 and 60 days after sprouting along with control and laid out in randomized block design, replicated thrice. All the growth regulating chemicals significantly increased the number of leaves clump ${ }^{-1}$, leaf area, LAI, blooming period of a spike with increasing concentrations except at high concentration of ethephon over control. Similar trend was followed for spike parameters also. However, days to $50 \%$ flowering and days to opening of first floret in a spike were significantly early in $\mathrm{GA}_{3}$ sprayed plants. $\mathrm{GA}_{3}$ excelled all other flower inducing chemicals for spike yield per hectare.

\section{Introduction}

Tuberose (Polianthes tuberosa L.) is native to Mexico and recently it has been placed under the family Asparagaceae. The area under this crop has been expanding at a faster rate, due to increased demand in both domestic and international market for its beautiful fragrant spikes. The long flower spikes are excellent cut flowers for table decoration. Among the commercial flowers cultivated in India, tuberose is extensively cultivated in an area of 7.77 thousand ha with a production of 40.22 thousand tonnes in Assam, Maharashtra, Gujarat, Haryana, Karnataka, Andhra Pradesh, Tamilnadu, West Bengal, Uttar Pradesh, 
Uttarakhand and Orissa. In Andhra Pradesh, the area under cultivation of tuberose accounts to 2,310 ha with a production of 13.88 thousand tonnes of flowers (NHB, 2015). Its commercial cultivation is more concentrated in East Godavari, Guntur, Chittoor, YSR Kadapa and Krishna districts of Andhra Pradesh.

The timing of the flower induction is of paramount importance in horticulture especially in floriculture. Exogenously applied growth regulating chemicals, act through the alteration in the levels of naturally occurring hormones, thus modifying the growth and development of the plant. These chemicals play an important role in overcoming the factors limiting the yield and quality of flowers by changing both morphology and physiology of plants. The response exhibited by plants to these chemicals varies with the species, cultivars, stage of the crop and concentration.

Hence, the present study is proposed to investigate the effect of different pre-harvest plant growth regulating chemicals on flower induction and development of tuberose spikes.

\section{Materials and Methods}

The experiment was carried out at Horticultural Research Station, Kovvur, West Godavari District, Andhra Pradesh, during 2015-2016 and 2016-2017 with the tuberose cv. Prajwal. Healthy and uniform bulbs with more than $2.0 \mathrm{~cm}$ diameter were used as planting material. Bulbs were planted at a spacing of $30 \mathrm{~cm} \times 30 \mathrm{~cm}$ at $5-6 \mathrm{~cm}$ depth in plots of $2.4 \times 2.4 \mathrm{~m}$ size. Well decomposed farmyard manure $25 \mathrm{t} \mathrm{ha}^{-1}$ was incorporated into all experimental plots uniformly at the time of last ploughing. Nitrogen, phosphorus and potassium were applied @ 200:200:200 $\mathrm{kg} \mathrm{ha}{ }^{-1}$ in the form of urea, single super phosphate and muriate of potash respectively.
Entire dose of phosphorus and potassium was applied as basal and nitrogen was applied in three split doses at 30, 60 and 90 days after planting. Irrigations were given at an interval of one to two weeks depending on the soil moisture.

There were eleven treatments, viz., Gibberellic Acid $\left(\mathrm{GA}_{3}\right)$ at 100 and $200 \mathrm{ppm}$, Salicylic Acid (SA) at 50 and 100 ppm, Benzyl Adenine (BA) at 50 and $100 \mathrm{ppm}$, Ethephon at 250 and 500 ppm, Spermidine at 50 and 100 ppm and water spray as control, replicated thrice in Randomized Block Design. As per the treatments, freshly prepared growth regulating chemicals mixed with commercial surfactant $(0.05 \%)$ were used for foliar sprays at 30 and 60 days after sprouting. Spraying was carried out during early morning, until the spray solution was run off all plants by using a manual sprayer. Observations on vegetative growth, flowering and yield parameters were recorded and statistically analyzed as per the methods given by Panse and Sukhatme (1989).

\section{Results and Discussion}

\section{Growth parameters}

\section{Number of leaves clump ${ }^{-1}$}

All the growth regulating chemicals significantly increased the number of leaves clump $^{-1}$ with increasing concentrations except ethephon over control (Table 1). Maximum number of leaves clump ${ }^{-1}$ was observed at BA $100 \mathrm{ppm}$ (99.66) followed by BA $50 \mathrm{ppm}$ (97.91) whereas lowest number of leaves clump $^{-1}$ was recorded in control (87.42) which was on par with ethephon 500 ppm (89.85). Increased leaf number by spraying BA over gibberellins was observed by Kumar and Gautam (2011) in tuberose. Increased production of leaves in BA sprayed plants might be attributed to enhanced induction of 
leaf initial break i.e., differentiation of leaf primordial in the apical growing region as reported by Singh (2010) in tuberose.

\section{Leaf area clump ${ }^{-1}\left(\mathrm{dm}^{2}\right)$}

Maximum leaf area clump ${ }^{-1}$ was recorded in plants treated with $\mathrm{GA}_{3} 200 \mathrm{ppm}\left(86.06 \mathrm{dm}^{2}\right)$ which was on par with $\mathrm{GA}_{3} 100$ ppm $(84.55$ $\mathrm{dm}^{2}$ ). The leaf area clump ${ }^{-1}$ was lowest in control $\left(75.49 \mathrm{dm}^{2}\right)$ and was on par with 500 ppm ethephon $\left(77.56 \mathrm{dm}^{2}\right.$ ) (Table 1). $\mathrm{GA}_{3}$ found to enhance the leaf area clump ${ }^{-1}$ as earlier reported by Rani and Singh (2013), Kurve (2016) in tuberose. The increase in leaf area might be due to the fact that $\mathrm{GA}_{3}$ enhances cell division and also involved in the leaf expansion (Yamaguchi, 2008) which led to elongated leaves (Sarkar et al., 2009) in tuberose.

Though the number of leaves produced by BA was more than $\mathrm{GA}_{3}$, the leaf area was more in $\mathrm{GA}_{3}$. This might be due to the role of $\mathrm{GA}_{3}$ in leaf expansion due to cell elongation and improved plasticity.

\section{Leaf Area Index (LAI)}

The maximum LAI was noticed in plants sprayed with $\mathrm{GA}_{3} 200$ ppm (9.563) followed by $\mathrm{GA}_{3} 100$ ppm (9.395). The minimum LAI was recorded in plants sprayed with water (8.388) which was on par with ethephon 500 ppm (8.620) (Table 1). The highest leaf area index with $\mathrm{GA}_{3}$ might be due to enhanced leaf area induced by gibberellins through cell elongation, cell division or both (Singh et al., 1991). The results are in conformity with the finding of Sarkar et al., (2009) in tuberose.

\section{Flowering parameters}

\section{Days to $50 \%$ flowering (d)}

Earliest 50\% flowering was observed in plants sprayed with $\mathrm{GA}_{3} 200$ ppm (97.77 d) which was on par with $\mathrm{GA}_{3} 100$ ppm (99.51 d) and SA $100 \mathrm{ppm}(101.32 \mathrm{~d})$. The flowering was delayed in plants sprayed with ethephon 500 ppm (111.46 d) which was on par with control (108.21 d) (Table 2). Application of $\mathrm{GA}_{3}$ at both the concentrations and SA at high concentration had significant stimulatory effect on days to $50 \%$ flowering compared to control. Comparatively SA treatments were less effective than $\mathrm{GA}_{3}$. Similar results were reported by Saidulu et al., (2016) in marigold.

$\mathrm{GA}_{3}$ application enhanced vegetative growth parameters viz., leaf area and LAI which in turn enhanced the photosynthetic activity and translocation of food materials to shoot apex for the development of floral primordia, advanced bud formation and onset of flowering. The results are in accordance with the findings of Sarkar et al., (2009), Sultana et $a l .$, (2016) in tuberose.

Further, Kumar and Gautam (2011) explained that $\mathrm{GA}_{3}$ at high concentration reduce juvenile period and at the termination of juvenile phase apical meristem starts producing flowers instead of vegetative growth and hence early flowering in tuberose. It is evident at molecular level that GA is perceived by a soluble receptor protein, GID1. Downstream of GID1 was controlled by a family of nuclear growth repressor proteins, DELLAs. Accumulation of DELLAs in turn represses LFY and SOC1 genes, thus flowering was delayed. DELLAs subsequently regulate the development of flowers themselves, via transcriptional repression of the floral homeotic genes APETALA3, PISTILLATA, and AGAMOUS. Thus, GA promotes growth and flowering via destruction of DELLAs (Achard et al., 2007).

\section{Days to emergence of spike (d)}

Among different growth regulating chemicals, the lowest number of days taken for spike emergence was registered with $\mathrm{GA}_{3} 200$ ppm 
$(128.66 \mathrm{~d})$ and was on a par with $\mathrm{GA}_{3} 100$ ppm (130.98 d). However, the highest number of days taken for spike emergence was noticed with ethephon $500 \mathrm{ppm}$ (146.88 d) followed by control (142.56 d) (Table 2). GA 3 was found best for early spike initiation as reported by several workers viz., Gawai et al., (2014), Ajmeera et al., (2015) in tuberose.

Early spike emergence was observed at both the concentrations of $\mathrm{GA}_{3}$ over the other treatments might be due to an induced alteration in source/sink relationships as suggested by Sachs (1977) who proposed the 'nutrient diversion' theory which proclaims that chemical induction of flowering might be the result of greater source or sink activity, leading to an increased carbohydrate status of the apex.

\section{Days to opening of first floret (d)}

Less number of days was taken for opening of first floret in a spike with $\mathrm{GA}_{3} 200$ ppm (17.26 d) sprayed plants. However, ethephon 500 ppm sprayed plants took more number of days for opening of first floret in a spike $(19.27 \mathrm{~d})$ which was on par with control (19.11 d). The results pertaining to $\mathrm{SA}, \mathrm{BA}$ and spermidine were intermediary (Table 2).

Opening of first floret in a spike was earlier with $\mathrm{GA}_{3}$ over other plant growth regulating chemicals. The results are in line with the findings of Kumar and Gautam (2011), Shanker and Sharma (2012) in tuberose. The opening of the first floret in a spike is dependent on the mobilization of sugars to the developing young florets. It could be evident from the present experiment that $\mathrm{GA}_{3}$ application increased leaf area and LAI which might have favoured the synthesis of more carbohydrates and better partitioning of assimilates towards the developing young florets.

\section{Days to opening last floret (d)}

The number of days required for opening of last floret in a spike did not differed significantly with the application of different growth regulating chemicals.

\section{Blooming period (d)}

Significantly the longest blooming period $(19.50 \mathrm{~d})$ was observed in plants sprayed with $\mathrm{GA}_{3} 200 \mathrm{ppm}$ (Table 2). The present results are line with those reported by Shanker and Sharma (2012), Rani and Singh (2013), Ajmeera et al., (2015) in tuberose. The longest blooming period with $\mathrm{GA}_{3} 200 \mathrm{ppm}$ might be due to the early opening of the first floret, more number of florets spike ${ }^{-1}$ and continued supply of photoassimilates to the developing florets.

Shortest blooming period was recorded with ethephon 500 ppm (17.45 d) spray and on par with control (17.61 d) (Table 2). The shortest blooming period was recorded with ethephon 500 ppm might be due to the delayed opening of the first floret and presence of less number of florets spike ${ }^{-1}$. Singh et al., (2010) also observed the reduced blooming period at higher concentration of ethephon (1000 ppm) in tuberose cv. Double. Less number of florets spike $^{-1}$ were promulgated as a reason for a constricted length of duration between opening of first and last floret in a spike.

\section{Spike parameters and spike yield}

\section{Length of spike (cm)}

The longest spike length was observed in plants sprayed with $\mathrm{GA}_{3} 200 \mathrm{ppm}(111.16 \mathrm{~cm})$ which was on par with $\mathrm{GA}_{3} 100$ ppm (109.21 $\mathrm{cm})$ while the spike length was shortest in plants sprayed with ethephon 500 ppm (97.96 $\mathrm{cm})$ which was on par with control (100.44 $\mathrm{cm}$ ) (Table 3). 
Table.1 Effect of different growth regulating chemicals on growth parameters in tuberose cv. Prajwal

\begin{tabular}{|c|c|c|c|}
\hline Treatments & $\begin{array}{c}\text { Number of } \\
\text { leaves clump }\end{array}$ & $\begin{array}{c}\text { Leaf area }\left(\mathrm{dm}^{2}\right) \\
\text { clump }^{-1}\end{array}$ & $\begin{array}{c}\text { Leaf area } \\
\text { Index (LAI) }\end{array}$ \\
\hline$T_{1}: G_{3} 100$ ppm & 95.63 & 84.55 & 9.395 \\
\hline$T_{2}: G_{3} 200$ ppm & 96.16 & 86.06 & 9.563 \\
\hline $\mathrm{T}_{3}: \mathrm{SA} 50 \mathrm{ppm}$ & 93.54 & 80.78 & 8.975 \\
\hline $\mathrm{T}_{4}: \mathrm{SA} 100 \mathrm{ppm}$ & 94.41 & 81.53 & 9.059 \\
\hline $\mathrm{T}_{5}: \mathrm{BA} 50$ ppm & 97.91 & 82.59 & 9.177 \\
\hline$T_{6}:$ BA 100 ppm & 99.66 & 83.04 & 9.227 \\
\hline $\mathrm{T}_{7}$ : Ethephon $250 \mathrm{ppm}$ & 90.91 & 78.51 & 8.724 \\
\hline$T_{8}:$ Ethephon 500 ppm & 89.85 & 77.56 & 8.620 \\
\hline T. $_{9}$ Spermidine 50 ppm & 91.79 & 79.27 & 8.808 \\
\hline$T_{10}:$ Spermidine 100 ppm & 92.66 & 80.02 & 8.891 \\
\hline $\begin{array}{l}\text { T }_{11}: \text { Water spray } \\
\text { (Control) }\end{array}$ & 87.42 & 75.49 & 8.388 \\
\hline Mean & 93.63 & 80.86 & 8.984 \\
\hline S.Em & 0.85 & 0.73 & 0.082 \\
\hline C.D. at $5 \%$ & 2.50 & 2.17 & 0.240 \\
\hline
\end{tabular}

$\mathrm{GA}_{3}$ : Gibberellic acid; SA: Salicylic acid; BA: Benzyl Adenine

Table.2 Effect of different growth regulating chemicals on days to $50 \%$ flowering, days to spike emergence, floret opening and blooming period of a spike in tuberose cv. Prajwal

\begin{tabular}{|c|c|c|c|c|c|}
\hline Treatments & $\begin{array}{l}\text { Days to } \\
\mathbf{5 0 \%} \\
\text { flowering } \\
\text { (d) }\end{array}$ & $\begin{array}{l}\text { Days to } \\
\text { emergence } \\
\text { of spike } \\
\text { (d) }\end{array}$ & $\begin{array}{l}\text { Days to } \\
\text { opening of } \\
\text { first floret } \\
\text { (d) }\end{array}$ & $\begin{array}{l}\text { Days to } \\
\text { opening of } \\
\text { last floret } \\
\text { (d) }\end{array}$ & $\begin{array}{l}\text { Blooming } \\
\text { period of a } \\
\text { spike }(d)\end{array}$ \\
\hline$T_{1}: G_{3} 100$ ppm & 99.51 & 130.98 & 17.57 & 36.73 & 19.16 \\
\hline$T_{2}: G_{3} 200 \mathrm{ppm}$ & 97.77 & 128.66 & 17.26 & 36.76 & 19.50 \\
\hline $\mathrm{T}_{3}: \mathrm{SA} 50 \mathrm{ppm}$ & 101.88 & 134.13 & 17.99 & 36.70 & 18.71 \\
\hline$T_{4}: S A 100$ ppm & 101.32 & 133.39 & 17.89 & 36.71 & 18.82 \\
\hline $\mathrm{T}_{5}:$ BA 50 ppm & 104.17 & 137.17 & 18.39 & 36.70 & 18.30 \\
\hline $\mathrm{T}_{6}: \mathrm{BA} 100 \mathrm{ppm}$ & 103.20 & 135.89 & 18.22 & 36.70 & 18.47 \\
\hline $\mathrm{T}_{7}$ : Ethephon 250 ppm & 107.17 & 141.17 & 18.92 & 37.30 & 18.38 \\
\hline $\mathrm{T}_{8}:$ Ethephon 500 ppm & 111.46 & 146.88 & 19.27 & 36.73 & 17.45 \\
\hline $\mathrm{T}_{9}$ : Spermidine 50 ppm & 106.15 & 139.81 & 18.74 & 36.71 & 17.96 \\
\hline$T_{10}:$ Spermidine 100 ppm & 105.15 & 138.48 & 18.57 & 36.70 & 18.13 \\
\hline$T_{11}:$ Water spray (Control) & 108.21 & 142.56 & 19.11 & 36.71 & 17.61 \\
\hline Mean & 103.78 & 136.66 & 18.36 & 36.77 & 18.41 \\
\hline S.Em & 1.35 & 1.56 & 0.06 & - & 0.06 \\
\hline C.D. at 5\% & 3.97 & 4.61 & 0.18 & NS & 0.18 \\
\hline
\end{tabular}

$\mathrm{GA}_{3}$ : Gibberellic acid; SA: Salicylic acid; BA: Benzyl Adenine 
Table.3 Effect of different plant growth regulating chemicals on spike characters in tuberose cv. Prajwal

\begin{tabular}{|c|c|c|c|c|c|}
\hline Treatments & $\begin{array}{l}\text { Length of } \\
\text { spike }(\mathrm{cm})\end{array}$ & $\begin{array}{l}\text { Length of } \\
\text { rachis } \\
\text { (cm) }\end{array}$ & $\begin{array}{l}\text { Girth of } \\
\text { spike } \\
\text { (cm) }\end{array}$ & $\begin{array}{l}\text { No. of } \\
\text { florets } \\
\text { spike }^{-1}\end{array}$ & $\begin{array}{c}\text { Floret } \\
\text { weight } \\
\text { spike }^{-1}(\mathrm{~g})\end{array}$ \\
\hline$T_{1}: G_{3} 100$ ppm & 109.21 & 39.25 & 4.34 & 51.82 & 95.45 \\
\hline$T_{2}: G A_{3} 200 \mathrm{ppm}$ & 111.16 & 39.95 & 4.42 & 52.75 & 97.15 \\
\hline $\mathrm{T}_{3}: \mathrm{SA} 50 \mathrm{ppm}$ & 106.68 & 38.34 & 4.24 & 50.62 & 93.23 \\
\hline $\mathrm{T}_{4}: \mathrm{SA} 100 \mathrm{ppm}$ & 107.26 & 38.55 & 4.26 & 50.90 & 93.74 \\
\hline$T_{5}:$ BA $50 \mathrm{ppm}$ & 104.34 & 37.50 & 4.15 & 49.51 & 91.19 \\
\hline$T_{6}: B A 100 \mathrm{ppm}$ & 105.31 & 37.85 & 4.18 & 49.97 & 92.04 \\
\hline $\mathrm{T}_{7}:$ Ethephon $250 \mathrm{ppm}$ & 101.41 & 36.45 & 4.03 & 48.12 & 88.63 \\
\hline$T_{8}:$ Ethephon 500 ppm & 97.96 & 35.20 & 3.91 & 47.66 & 86.04 \\
\hline $\mathrm{T}_{9}$ : Spermidine $50 \mathrm{ppm}$ & 102.39 & 36.80 & 4.07 & 48.59 & 89.48 \\
\hline $\mathrm{T}_{10}:$ Spermidine $100 \mathrm{ppm}$ & 103.36 & 37.15 & 4.11 & 49.05 & 90.33 \\
\hline $\begin{array}{l}T_{11}: \quad \text { Water spray } \\
\text { (Control) }\end{array}$ & 100.44 & 36.10 & 3.87 & 46.27 & 85.22 \\
\hline Mean & 104.50 & 37.56 & 4.14 & 49.57 & 91.14 \\
\hline S.Em & 0.87 & 0.32 & 0.01 & 0.17 & 0.31 \\
\hline C.D. at 5\% & 2.58 & 0.93 & 0.04 & 0.49 & 0.91 \\
\hline
\end{tabular}

$\mathrm{GA}_{3}$ : Gibberellic acid; SA: Salicylic acid; BA: Benzyl Adenine

Table.4 Effect of different plant growth regulating chemicals on spike yield in tuberose $\mathrm{cv}$. Prajwal

\begin{tabular}{|c|c|c|}
\hline Treatments & Number of spikes clump ${ }^{-1}$ & Number of spikes ha ${ }^{-1}$ (lakhs) \\
\hline$T_{1}: G A_{3} 100 \mathrm{ppm}$ & 2.056 & 1.830 \\
\hline$T_{2}: G A_{3} 200 \mathrm{ppm}$ & 2.092 & 1.862 \\
\hline$T_{3}: S A 50 \mathrm{ppm}$ & 2.008 & 1.787 \\
\hline$T_{4}: S A 100$ ppm & 2.019 & 1.797 \\
\hline $\mathrm{T}_{5}: \mathbf{B A} 50$ ppm & 1.964 & 1.748 \\
\hline $\mathrm{T}_{6}: \mathrm{BA} 100 \mathrm{ppm}$ & 1.982 & 1.764 \\
\hline$T_{7}:$ Ethephon 250 ppm & 1.909 & 1.699 \\
\hline$T_{8}$ : Ethephon 500 ppm & 1.876 & 1.667 \\
\hline $\mathrm{T}_{9}$ : Spermidine 50 ppm & 1.927 & 1.715 \\
\hline $\mathrm{T}_{10}:$ Spermidine 100 ppm & 1.946 & 1.732 \\
\hline $\begin{array}{l}\mathrm{T}_{11} \text { : Water } \\
\text { (Control) }\end{array}$ & 1.891 & 1.683 \\
\hline Mean & 1.970 & 1.753 \\
\hline S.Em & 0.007 & 0.006 \\
\hline C.D. at $5 \%$ & 0.020 & 0.017 \\
\hline
\end{tabular}

$\mathrm{GA}_{3}$ : Gibberellic acid; SA: Salicylic acid; BA: Benzyl Adenine 
Except at high concentration of ethephon, all the growth regulating chemicals increased the spike length over control. Significantly the longest spike length was noticed at both the concentrations of $\mathrm{GA}_{3}$. The results are in line with the findings of Rani and Singh (2013), Sultana et al., (2016), Amin et al., (2017) in tuberose.

Increased spike length with $\mathrm{GA}_{3}$ might be due to rapid internodal elongation that could be ascribed to the enhanced cell division, increased carbohydrate hydrolysis and increased cell-wall plasticity (Sachs, 1961). Acid invertase activity was increased in response to $\mathrm{GA}_{3}$ application and helps in hydrolysis of sucrose into hexose sugars. The hexose sugars thus formed were easily transported to the sink, thereby increasing sink strength and resulted in rapid elongation of flowering stalk (Iqbal et al., 2011).

Spike length was reduced with higher concentration of ethephon as compared to control. It was also demonstrated by Mukhopadhyay and Bankar, 1983 in tuberose. Ethephon application reduces the rate of DNA synthesis not only in the apical meristem, but also in elongating zone of the stem where no cell divisions occur. However, RNA synthesis is not affected in these tissues (Burg, 1973).

\section{Length of rachis $(\mathrm{cm})$}

Foliar spray with $\mathrm{GA}_{3} 200$ ppm recorded significantly longest rachis length $(39.95 \mathrm{~cm})$ followed by $\mathrm{GA}_{3} 100 \mathrm{ppm}(39.25 \mathrm{~cm})$ (Table $3)$. The results are in close conformity with the findings of Rani and Singh (2013), Amin et al., (2017) in tuberose.

Application of $\mathrm{GA}_{3}$ increased the rachis length which might be due to rapid internodal elongation which inturn could be a consequence of increased cell production and elongation in the intercalary meristem (Sauter and Kende, 1992).
Moreover, shortest rachis length was observed with ethephon 500 ppm $(35.20 \mathrm{~cm})$ which was on par with control $(36.10 \mathrm{~cm})$ (Table 3). Similar results were also observed by Singh et al., (2010) in tuberose.

Reduction in rachis length was noticed in ethephon treated plants due to inhibitory action of ethephon on cell elongation there by it reduced the internodal length.

\section{Girth of spike (cm)}

Among different growth regulating chemicals studied, maximum spike girth was recorded with $\mathrm{GA}_{3}$ treated plants. Significantly highest spike girth was registered in plants sprayed with $\mathrm{GA}_{3} 200$ ppm (4.42 cm) (Table 3). Similar results were reported Amin et al., (2017) in tuberose.

The lowest spike girth was observed in control $(3.87 \mathrm{~cm})$ which was on par with ethephon 500 ppm $(3.91 \mathrm{~cm})$ (Table 3).

Maximum number of florets spike $^{-1}$ was observed in plants sprayed with $\mathrm{GA}_{3} 200 \mathrm{ppm}$ (52.75) compared to control (46.27) (Table 3).

\section{Number of florets spike $e^{-1}$}

$\mathrm{GA}_{3}$ excelled all other flower inducing chemicals regarding number of florets spike ${ }^{-1}$. The results are in close conformity with the findings of Shanker et al., (2011), Rani and Singh (2013), Amin et al., (2017) in tuberose. $\mathrm{GA}_{3}$ increased the substrate availability at the time of flower initiation (Corr and Widmer, 1987) which resulted in increased number of florets spike ${ }^{-1}$.

\section{Floret weight spike ${ }^{-1}(\mathrm{~g})$}

All growth regulating chemicals improved the floret weight spike ${ }^{-1}$ over the control. Among different growth regulating chemicals applied, $\mathrm{GA}_{3} 200 \mathrm{ppm}$ registered highest floret weight 
spike $^{-1}(97.15 \mathrm{~g})$ and lowest floret weight spike $^{-1}$ was observed in control (85.22 g) which was on par with ethephon at $500 \mathrm{ppm}$ $(86.04 \mathrm{~g})$ (Table 3$)$. Increase in floret weight spike $^{-1}$ with $\mathrm{GA}_{3}$ was attributed to the production of more number of bigger size florets as gibberellins are important for differentiation and growth of more number of flower primordia (Alpi et al., 1976). These results are in line with the findings of Sajjad et al., (2015) in gladiolus.

\section{Number of spikes clump ${ }^{-1}$}

Application of $\mathrm{GA}_{3} 200$ ppm produced significantly more number of spikes clump ${ }^{-1}$ (2.092) whereas less number of spikes clump $^{-1}$ was produced in ethephon $500 \mathrm{ppm}$ (1.876) treatment which was on par with control (1.891) (Table 4).

Plants treated with $\mathrm{GA}_{3}$ at higher concentration produced more number of spikes than at low concentrations. Brooking and Cohen (2002) reported that high gibberellin doses induce more rapid floral initiation than lower doses. Further, Chang (1999) suggested that hydroxylated C-19 GAs play an important role in flower induction which was supported by the observations that there was an increase in endogenous $\mathrm{GA}_{20}$ level coincided with the transition from the vegetative phase to early floral initiation and flower differentiation stages in tuberose. Similar results were recorded by Rani and Singh (2013), Amin et al., (2017) in tuberose.

\section{Number of spikes ha-1 (lakhs)}

Maximum number of spikes ha ${ }^{-1}$ was obtained from the plants sprayed with $\mathrm{GA}_{3} 200 \mathrm{ppm}$ (1.862 lakhs) while the minimum number of spikes ha-1 was recorded in ethephon 500 ppm (1.667 lakhs) which was on par with control (1.683 lakhs) (Table 4).
Increased production of spikes with $\mathrm{GA}_{3}$ might be due to promotion of cell division and regulation of differentiation of cells at the time of transformation of vegetative to floral primordial. Similar result was reported by Ajmeera et al., (2015) in tuberose.

Ethephon at higher concentration (500 ppm) produced significantly minimum number of spikes ha ${ }^{-1}$ compared to rest of the treatments and on par with control. Similarly, Singh (2010) noticed minimum mean spike yield $\mathrm{m}^{-}$ ${ }^{2}$ at higher concentration of ethrel (300 ppm) in tuberose.

Conclusion of the study is as follows:

From the present investigation it is revealed that foliar application of $\mathrm{GA}_{3}$ at both the concentrations significantly increased spike quality and yield of tuberose cv. Prajwal.

\section{References}

Achard, P., M. Baghour, A. Chapple, P. Hedden, D.V.D. Straeten and Genschik, P. 2007. The plant stress hormone ethylene controls floral transition via DELLA-dependent regulation of floral meristem-identity genes. Proceedings of the National Academy of Sciences U.S.A. 104 (15): $6484-6489$.

Ajmeera, R., S.S. Moon, C.N.R. Santhoshini and Shashank, A. 2015. Effect of foliar application of GA3 and chemicals on growth, flowering and yield of tuberose. Journal of Soils and Crops. 25(2): $358-$ 361.

Alpi, A., C. Ceccarelli, F. Tognoni and Gregorni, G. 1976. Gibberellin and inhibitor content during Iris bulb development. Physiologia Plantarum. 36: $362-367$.

Amin, M.R., N. Pervin, A. Nusrat, H. Mehraj and Uddin, A.F.M.J. 2017. Effect of plant growth regulators on growth and 
flowering of tuberose (Polianthes tuberosa L.) cv. Single. Journal of Bioscience and Agriculture Research. 12 (1): $1016-1020$.

Brooking, I.R., and Cohen, D. 2002. Gibberellin-induced flowering in small tubers of Zantedeschia 'Black Magic'. Scientia Horticulturae. 95(1-2): $63-73$.

Burg, S.P. 1973. Ethylene in plant growth. Proceedings of the National Academy of Sciences of the United States of America. 70(2): 591 - 597.

Chang, S.T. 1999. Changes in cytokinin and gibberellin levels before, during and after floral initiation in Polianthes tuberosa. M.Sc. Thesis. National Sun Yat-sen University, Gushan, Kaohsiung, Taiwan.

Corr, B.E., and Widmer, R.E. 1987. Gibberellic acid increases flower number in Zantedeschia elliottiana and Z. rehmannii. HortScience. 22(4): $605-$ 607.

Gawai, Y.R., R.D. Baghele and Gawai, Y.J. 2014. Effect of plant growth regulators on tuberose (Polianthe tuberosa L.). BIOINFOLET. 11: 709 -710.

Iqbal, N., R. Nazar, M.I.R. Khan, A. Masood, and Khan, N.A. 2011. Role of gibberellins in regulation of source-sink relations under optimal and limiting environmental conditions. Current Science. 100(7): 998 - 1007.

Kumar, A., and Gautam, D.K. 2011. Effect of plant growth regulators on vegetative growth and flowering behaviour of tuberose (Polianthes tuberosa Linn.) cv. Hyderabad Double. Plant Archives. 11(2): $919-921$.

Kurve, G. 2016. Effect of plant growth regulators on growth and flowering of tuberose (Polianthes tuberose Linn.). M.Sc. Thesis. Rajmata Vijayaraje Scindia Krishi Vishwa Vidyalaya, Gwalior, India.

Mukhopadhyay, A., and Bankar, G.J. 1983.
Regulation of growth and flowering in Polianthes tuberosa L. with gibberellic acid and ethrel spray. Scientia Horticulturae. 19(1-2): 149- 152.

NHB. 2015. Indian Horticulture Database 2014. IG Printer Pvt. Ltd. New Delhi. 286. www.nhb.gov.in

Panse, V.G., and Sukhatme, P.V. 1989. Statistical Methods for Agricultural Workers. Indian Council for Agricultural Research, New Delhi. 359.

Rani, P., and Singh, P. 2013. Impact of gibberellic acid pretreatment on growth and flowering of tuberose (Polianthes tuberosa L.) cv. Prajwal. Journal of Tropical Plant Physiology. 5: 33 - 41.

Sachs, R.M. 1961. Gibberellin, auxin, and growth retardant effects upon cell division and shoot histogenesis. Advances in Chemistry Series. 28: 49 58.

Sachs, R.M. 1977. Nutrient diversion: A hypothesis to explain the chemical control of flowering. Hort Science. 2: $220-222$.

Saidulu, Y., A. Girwani, and Chandrasekhar, R. 2016. Strategy to improve yield and shelf life of marigold flowers through pre-harvest foliar sprays. Environment and Ecology. 34 (3C): 1546 - 1550.

Sajjad, Y., M.J. Jaskani, M. Qasim, G. Akhtar and Mehmood, A. 2015. Foliar application of growth bioregulators influences floral traits, corm associated traits and chemical constituents in Gladiolus grandiflorus L. Korean Journal Horticultural Science Technology. 33(6): $812-819$.

Sarkar, J., R.L. Misra, S.K. Singh, K.V. Prasad and Arora, A. 2009. Effect of growth regulators on growth and flowering in tuberose under north India conditions. Indian Journal of Horticulture. 66(4): 502 - 507.

Sauter, M., and Kende, H. 1992. Gibberellin induced growth and regulation of the 
cell division cycle in deep water rice. Planta. 188: 362 - 368.

Shanker, K., and Sharma, M.M. 2012. Effect of plant growth regulators on vegetative growth and flowering behaviour of tuberose (Polianthes tuberosa Linn.) cv. Double. Journal of Interacademicia. 16(3): $598-601$.

Singh, B. 2010. Influence of foliar application of plant growth regulators on growth, flowering and postharvest life of tuberose (Polianthes tuberosa L.). Ph.D. Thesis. Govind Ballabh Pant University of Agriculture \& Technology, Pantnagar, Uttarakhand, India.

Singh, M.P., R.P. Singh and Singh, G.N.
1991. Effect of GA3 and ethrel on the growth and flowering of African marigold (Tagetes erecta L.). Haryana Journal of Horticultural Sciences. 20 (12): $81-84$.

Sultana, S., M.R. Amin, M.I. Hossain, and Sarkar, M.D. 2016. Response of GA3 to morphological characteristics of tuberose incorporated with organic manures. International Journal of Scientific and Research. 6(12): $384-$ 388.

Yamaguchi, S. 2008. Gibberellin metabolism and its regulation. Annual Review of Plant Biology. 59: 225 - 251.

\section{How to cite this article:}

Naga Lakshmi, R., M. Lakshminarayana Reddy, B. V. K. Bhagavan, A. V. D. Dorajee Rao, P. Subbaramamma and Uma Krishna, K. 2020. Response of Tuberose (Polianthes tuberosa L.) cv. Pajwal to Flower Inducing Chemicals. Int.J.Curr.Microbiol.App.Sci. 9(01): 253-269. doi: https://doi.org/10.20546/ijcmas.2020.901.029 